\title{
Charpy 衝撃試験の特性が鋼構造部材の耐力に及ぼす影響 EFFECT OF THE PROPERTIES OF CHARPY IMPACT TEST ON STEEL STRUCTURE BEARING LOAD
}

\author{
新井佑一郎*, 小中孔明*, 半貫敏夫**, 秋山 宏*** \\ Yuichiro ARAI, Koumei KONAKA, Toshio HANNUKI \\ and Hiroshi AKIYAMA
}

\begin{abstract}
Charpy impact test has been established as a convenient evaluation method for the toughness of steel materials. Since the Hyogo-ken Nanbu earthquake, even in the field of building structures, technical standards to prevent the brittle fracture of steel members have been introduced and the required value of the Charpy energy absorption has been standardized. However, the result of Charpy impact tests differ widely depending on the material properties. Therefore, it becomes important to clarify the correspondence between the difference of the result of Charpy tests and the ductility of real structures. In this investigation, using two materials which have different properties in terms of Charpy test, the full scale test on the structural behavior was carried out. Under the controlled temperature, the difference of the full scale test was minutely examined by comparing the difference of the Charpy energy transition curve of materials.
\end{abstract}

\section{Keywords : Beam-to-Column Connections, Charpy Impact Test, Ductile Fracture \\ Brittle Fracture, Fracture Transition Curve, Upper Shelf Energy \\ 柱梁接合部，Charpy 衝撃試験，延性破壊，脆性破壊，破壊遷移曲線，上部棚吸収エネルギー}

\section{1. はじめに}

鋼構造部材における脆性破壊は、而震設計上好ましくない終局状 態である。このため、設計・施エレベルで脆性破壊を回避させるた めの配慮が必要となる。脆性破壊は船舶や圧力容器のような大型溶 接構造物を用いる分野で、比較的早期から研究が進められ、知見が 蓄積されてきた。この結果、鋼素材の勒性をパラメータとすること で構造物の脆性破壊を回避できることが示されている。

建築構造分野では、1960 年代から実験室レベルでの大断面部材の 脆性破壊が確認・報告されてきたが 1) 3)、本格的な注目を集めるの は 1994 年の米国ノースリッジ地震と 1995 年の兵庫県南部地震での 被害報告 4 )からである。建築鋼構造部材の脆性破壊は、大半が塑性 変形がある程度進んだ後に延性亀裂を起点として生じる高応力脆性 破壊である。これは疲労亀裂を起点とした船舶や圧力容器のそれと は異なる破壞形式である。

脆性破壊を回避する上での最も基本的な評価手法として Charpy 衝撃試験が広く用いられている。造船を対象とした初期の研究では、 脆性破壊防止のクライテリアとして 10～20ft-lb(13～27J)が示され た 5)。建築構造物でも兵庫県南部地震以降、研究が進められデータ が蓄積された。この結果、日本建築センターの梁端溶接部の脆性的 破断防止マニュアル 6)が整備され、耐力保証のクライテリアとして $0^{\circ} \mathrm{C}$ の Charpy 吸収エネルギーが $70 \mathrm{~J}$ 以上と示された。しかし、鋼
構造部材の実大実験に関する統計的調查から、脆性破壊領域では耐 力のバラつきが大きいことが示され 7)、70J と言うクライテリアの みではまだ不安が残るのも事実である。

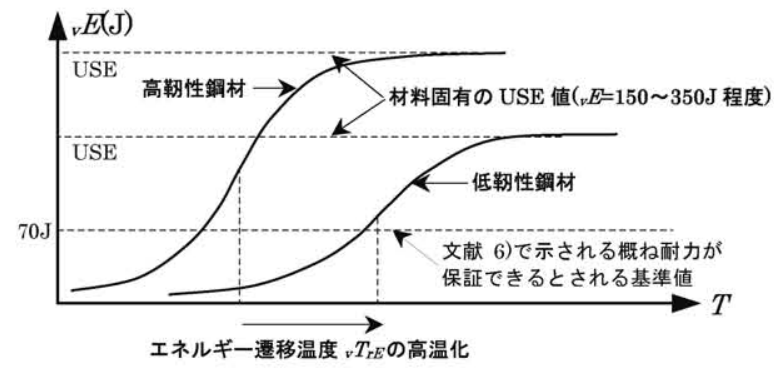

図 1 Charpy 吸収エネルギー遷移曲線の材料による変化

Charpy 衝撃試験による素材勒性の温度依存性を表す指標として、 脆性から延性を網羅する温度レンジで試験を行うことで評価できる 遷移曲線がある。図 1 は Charpy 衝撃試験の吸収エネルギー遷移曲 線を模式的に示したものである。図 1 中には比較例として、高勒性 材料と低勒性材料の吸収エネルギー遷移曲線を示した。

Charpy 吸収エネルギー $E E$ は低温域ではほぼ 0 に近い值を示し、 試験温度の上昇とともに増加して、十分高温になると值が飽和する。 この飽和値を上部棚吸収エネルギー(Upper Shelf Energy: USE)と
* 日本大学大学院理工学研究科建築学専攻 大学院生

*** 日本大学理工学部建築学科 教授. 工博

*** 東京大学 名誉教授·工博
Graduate Student, Architecture Major, Graduate School of Science and Technology, Nihon Univ.

Prof., Dept. of Architecture, College of Science and Technology, Nihon Univ., Dr. Eng. Prof. Emeritus, Univ. of Tokyo, Dr. Eng. 
いう ${ }^{8), 9)}$ 。そして、 $v E$ の変化している領域が遷移領域であり、その 中間 $(v E=\mathrm{USE} / 2)$ に対応する温度をエネルギー遷移温度 $、 T_{r E}$ という。 図 1 から、エネルギー遷移温度 ${ }_{v} T_{r E}$ や USE は、遷移曲線から読み 取れる材料固有の值であるといえる。このような遷移曲線を用いた 評価を取り入れている原子炉圧力容器の健全性評価では、素材の USE も評価ポイントとしている ${ }^{8.99}$ 。

本論では、Charpy 衝撃試験結果の特性が異なる 2 種類の鋼材(低 勒性材: SM490A, 高勒性材: SS400)を使用し、接合部をモデル化し た試験体により、温度をパラメータとした接合部破壊実験を行った。 実験結果に、既往の実験結果 10) 15)を加えて、Charpy 衝撃試験の工 ネルギー遷移曲線を用いた耐力評価を行った。

\section{2. 実験概要}

\section{1 素材の選択}

本論では、素材特性が異なる 2 種類の鋼材、SM490A PL- 25 平鋼, SS400 PL-22 厚板の電炉鋼材を使用した。素材はともに市場流通品 であるが、SM490A 電炉平鋼についてはメーカーの協力のもとに、 勒性が低いものを選択した。SS400 電炉厚板は市場から無作為に選 定したものである。 $490 \mathrm{~N} ， 400 \mathrm{~N}$ 級の異なる強度ランクの素材を用 いた理由は、化学成分が異なる素材間での比較検討を行うためでも ある。表 1 に、用いた素材の化学成分值(ミルシート)を示す。

表 1 素材の化学成分値(ミルシート値)

\begin{tabular}{|c|c|c|c|c|c|c|c|c|}
\hline \multirow{2}{*}{ 鋼種 } & \multirow[t]{2}{*}{ 寸法 } & \multicolumn{5}{|c|}{ 化学成分(\%) } & \multirow{2}{*}{$\begin{array}{l}\text { Ceq } \\
(\%)\end{array}$} & \multirow{2}{*}{$\begin{array}{c}\begin{array}{c}\mathrm{Pcm} \\
(\%)\end{array} \\
\end{array}$} \\
\hline & & $\mathrm{C}$ & $\mathrm{Si}$ & $\mathrm{Mn}$ & $\mathrm{P}$ & $\mathrm{S}$ & & \\
\hline & & 0.14 & 0.20 & 1.3 & 0.018 & 0.009 & 0.37 & 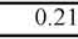 \\
\hline & & 0 & 0. & & $\overline{0.0}$ & 0. & & \\
\hline
\end{tabular}

表 1から、SM490A材についてはごく一般的な值を示しているが、 $\mathrm{SS} 400$ 材の C が $0.06 \%$ と少なく、 $\mathrm{Mn}, \mathrm{Si}$ の量が一般的な SS400よ りも高い值を示した。

\section{2 素材の Charpy 衝撃試験}

2.1 節で示した素材の Charpy 衝撃試験を行い、吸収エネルギー ${ }_{v} E$ と脆性破面率 $C_{r y}$ を計測した。衝撃試験の試験温度は遷移領域の温 度帯とし、遷移曲線のフルカーブが得られるように設定した。
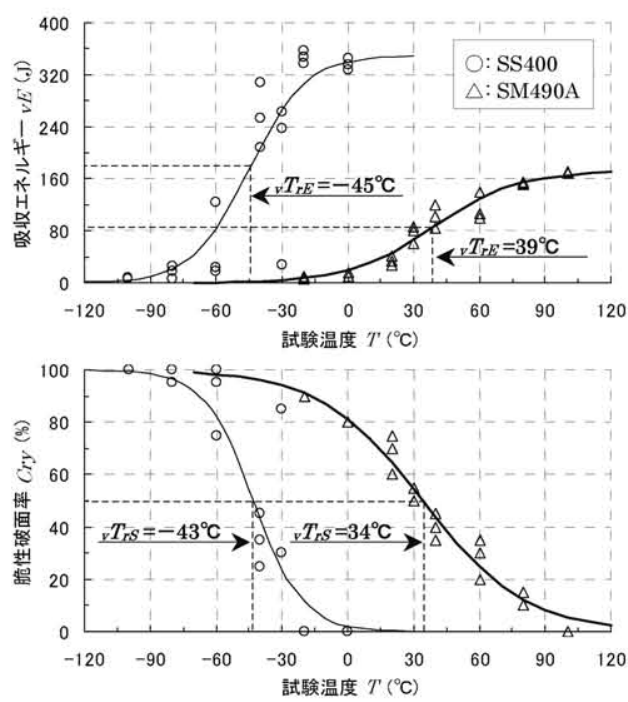

図 2 SM490A, SS400 Charpy 衝撃試験結果
図 2 中の遷移曲線は式(1),(2)で定義した近似式を用い、非線形最 小二乗法により誤差が最小になるように決定した。

$$
\begin{aligned}
& { }_{v} E=\frac{{ }_{v} E_{U S E}}{\exp \left\{-a\left(T-{ }_{v} T_{r E}\right)\right\}+1} \\
& C_{r y}=\frac{100}{\exp \left\{-b\left(T-{ }_{v} T_{r S}\right)\right\}+1} \\
& { }_{v} E_{U S E} \text { : 上部棚における吸収エネルギー(J) } \\
& T \text { : 試験温度 }\left({ }^{\circ} \mathrm{C}\right) \\
& { }_{v} T_{r E} \text { : Charpy吸収エネルギー遷移温度 }\left({ }^{\circ} \mathrm{C}\right) \\
& { }_{v} T_{r S} \text { : Charpy脆性破面率遷移温度 }\left({ }^{\circ} \mathrm{C}\right) \\
& a, b \text { : 最小二乗法により求められた定数 }
\end{aligned}
$$

表 2 Charpy 衝撃試験による評価値

\begin{tabular}{|c|c|c|c|c|c|c|}
\hline 鋼種 & $\begin{array}{c}N D T \\
\left({ }^{\circ} \mathrm{C}\right)\end{array}$ & $\begin{array}{c}N D T+30^{\circ} \mathrm{C} \\
\left({ }^{\circ} \mathrm{C}\right)\end{array}$ & $\begin{array}{c}{ }^{2} T_{r E} \\
\left({ }^{\circ} \mathrm{C}\right)\end{array}$ & $\begin{array}{c}{ }^{v}{ }_{r S} \\
\left({ }^{\circ} \mathrm{C}\right)\end{array}$ & $\begin{array}{c}{ }^{v} E_{0} \\
(\mathrm{~J})\end{array}$ & $\begin{array}{c}\text { USE } \\
(\mathrm{J})\end{array}$ \\
\hline $\mathrm{SM} 490 \mathrm{~A}$ & -7 & 23 & 39 & 34 & 19 & 172 \\
\hline $\mathrm{SS} 400$ & -63 & -33 & -45 & -43 & 340 & 350 \\
\hline
\end{tabular}

図 2 の Charpy 衝撃試験結果から評価した NDT, エネルギー遷移 温度 ${ }_{v} T_{r E}$, 破面遷移温度 ${ }_{v} T_{r S}, 0^{\circ} \mathrm{C}$ における吸収エネルギー ${ }_{v} E_{0}$, 上 部棚吸収エネルギーUSE を表 2 に示寸。表 2 中の NDT は脆性破面 率 $85 \%$ に対応する温度である。既往の実験から、鋼構造部材の延性 破壊を保証する温度レベルとして $\mathrm{NDT}+30^{\circ} \mathrm{C}$ 程度が提唱されてい る11ので、これも表 2 中に示した。

Charpy 衝撃試験の結果、本実験で用いた SM490A 材は遷移温度 が高く、 $v E_{0}=19 \mathrm{~J}, \mathrm{USE}=172 \mathrm{~J}$ と低いため、低勒性の鋼材であると判 断できる。SS400 材は、遷移温度が低く、 $v E_{0}=340 \mathrm{~J}, \mathrm{USE}=350 \mathrm{~J}$ と 非常に高いため、高勒性の鋼材と判断できる。

\section{3 試験体概要}

実大試験体の概要を示す。本実験では、梁端接合部, 梁部材の挙 動および破壊状態のみを確認するため、柱部材を剛とみなし、片持 ち梁形式に単純化した。これにより、パネルゾーンの挙動や梁ウェ

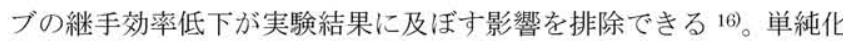

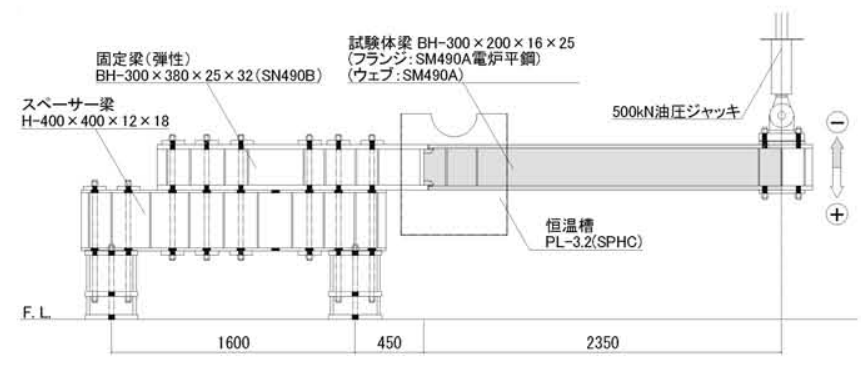

図 3490 シリーズ試験体

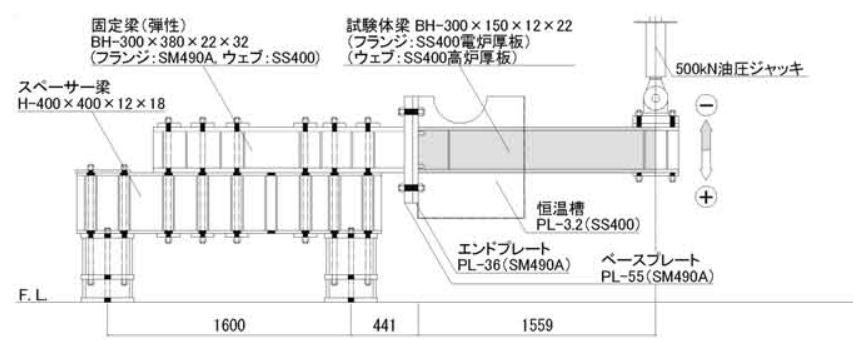

図 4400 シリーズ試験体 
試験体の概要を図 3,4 に示寸。図 3,4 中の網掛け部分が試験体梁で ある。図 3 は低勒性の SM490A 材を、図 4 は高勒性の SS400 材を 破壊想定位置の梁フランジ材に用いた試験体である。以下、図 3 の 試験体を 490 シリーズ、図 4 の試験体を 400 シリーズと呼ぶ。梁フ ランジ材以外の使用材料は図 3,4 中に示す通りである。試験体梁部 分は両シリーズともに溶接組み立て $\mathrm{H}$ 形断面であるが、490 シリー ズでは $\mathrm{BH}-300 \times 200 \times 16 \times 25 、 400$ シリーズでは $\mathrm{BH}-300 \times 150$ $\times 12 \times 22$ とした。400 シリーズ試験体は、エンドプレート方式を採 用することで、試験体梁のみを交換できるようにしてある。両シリ 一ズともに梁端部の試験温度を管理するための恒温槽が取り付けら れている。

490 シリーズ及び 400 シリーズの試験体接合部詳細をそれぞれ図 5,6 に示す。接合部は既往の実験 11) 13) との比較のため従来型スカ ラップとし、スカラップ底は回し溶接されている。梁フランジ溶接 端部に用いた鋼製エンドタブを $10 \mathrm{~mm}$ 程度残して切削した。 400 シ リーズの接合部は 490 シリーズからダイアフラム要素を省略し、更 に単純化したものである。ただし、スカラップ底の形状, エンドタ ブなど破壊起点となり得る部分の基本条件は両シリーズとも共通で ある。

梁フランジの溶接条件を表 3 に示す。パス間温度は両試験体とも に $200^{\circ} \mathrm{C}$ 以下に管理し、溶接熱影響による材質の劣化が最小限にな るように配慮した ${ }^{17) 。 ~}$
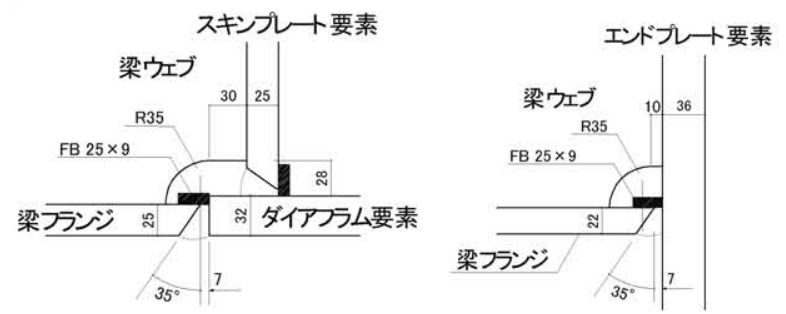

図 5490 シリーズ接合部詳細 図 6400 シリーズ接合部詳細

表 3 梁フランジ接合部溶接条件

\begin{tabular}{|c|c|c|c|c|c|c|}
\hline 試験体 & 溶接ワイヤー & パス数 & $\begin{array}{c}\text { 電流 } \\
(\mathrm{A})\end{array}$ & $\begin{array}{c}\text { 電圧 } \\
(\mathrm{V})\end{array}$ & $\begin{array}{c}\text { 入熱量 } \\
(\mathrm{kJ} / \mathrm{cm})\end{array}$ & $\begin{array}{c}\text { パス間温度 } \\
\left({ }^{\circ} \mathrm{C}\right)\end{array}$ \\
\hline 490 シリーズ & YGW11 $1.2 \varphi$ & 13 & $280 \sim 300$ & $29 \sim 31$ & $12 \sim 28$ & $200^{\circ} \mathrm{C}$ 以下 \\
\hline 400 シリーズ & YGW11 $1.2 \varphi$ & 7 & $250 \sim 330$ & $24 \sim 34$ & $12 \sim 23$ & $200^{\circ} \mathrm{C}$ 以下 \\
\hline
\end{tabular}

\section{4 試験温度をパラメータとした梁フランジ材の引張試験}

試験体の主要部分に用いる鋼材について引張試験を行った。破壊 起点となることが予想される梁フランジ材については、素材特性一 温度関係を詳細に把握するために、試験温度をパラメータとした引 張試験を行った。引張試験片は JS -5 号に準拠している。試験温 度は SM $490 \mathrm{~A}$ で $+50^{\circ} \mathrm{C} \sim-69^{\circ} \mathrm{C}(9$ 体 $), \mathrm{SS} 400$ で $+17^{\circ} \mathrm{C} \sim-72^{\circ} \mathrm{C}(6$
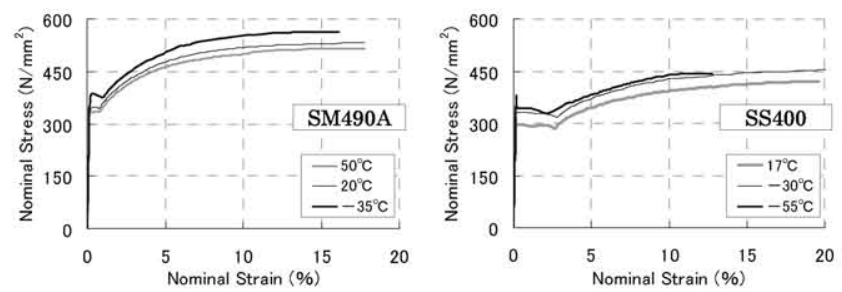

図 7 梁フランジ材の公称応力度一公称ひずみ度関係
表 4 SM490A 素材特性一温度関係

\begin{tabular}{|c|c|c|}
\hline \multirow{2}{*}{ 降伏応力度 } & \multirow{2}{*}{${ }_{n} \sigma_{y}\left(\mathrm{~N} / \mathrm{mm}^{2}\right)$} & {$\left[\leqq-20^{\circ} \mathrm{C}\right]{ }_{n} \sigma_{y}(T)=-1.2 T+342.2$} \\
\cline { 3 - 3 } & & {$\left[\geqq-20^{\circ} \mathrm{C}\right]{ }_{n} \sigma_{v}(T)=-0.4 T+358.2$} \\
\hline 引張強さ & ${ }_{n} \sigma_{u}\left(\mathrm{~N} / \mathrm{mm}^{2}\right)$ & ${ }_{n} \sigma_{u}=-0.75 T+545.4$ \\
\hline 降伏棚のびみ度 & $\varepsilon_{y o}(\%)$ & $\varepsilon_{y 0}(T)=0.86$ \\
\hline ヤング係数 & ${ }_{n} E\left(\mathrm{~N} / \mathrm{mm}^{2}\right)$ & ${ }_{n}{ }_{n}(T)=205000$ \\
\hline \multirow{2}{*}{ ひずみ硬化勾配 } & \multirow{2}{*}{$E_{t} E_{t}\left(\mathrm{~N} / \mathrm{mm}^{2}\right)$} & {$\left[\leqq-20{ }^{\circ} \mathrm{C}\right]{ }_{t} \sigma_{t}(T)=22.5 T+5530$} \\
\cline { 3 - 3 } & & {$\left[\geqq-20^{\circ} \mathrm{C}\right]{ }_{t} \sigma_{t}(T)=-6.7 T+4946$} \\
\hline
\end{tabular}

表 5 SS400 素材特性一温度関係

\begin{tabular}{|c|c|c|}
\hline 上降伏応力度 & ${ }_{n} \sigma_{v l}\left(\mathrm{~N} / \mathrm{mm}^{2}\right)$ & ${ }_{n} \sigma_{y l}(T)=-0.83 T+327.9$ \\
\hline 下降伏応力度 & ${ }_{n} \sigma_{v 2}\left(\mathrm{~N} / \mathrm{mm}^{2}\right)$ & ${ }_{n} \sigma_{y 2}(T)=-0.77 T+303.4$ \\
\hline 引張強さ & ${ }_{n} \sigma_{u}\left(\mathrm{~N} / \mathrm{mm}^{2}\right)$ & ${ }_{n} \sigma_{u}(T)=-0.74 T+434.6$ \\
\hline 降伏棚のひずみ度 & $\varepsilon_{y 0}(\%)$ & $\varepsilon_{v 0}(T)=2.42$ \\
\hline ヤング系数 & ${ }_{n} E\left(\mathrm{~N} / \mathrm{mm}^{2}\right)$ & ${ }_{n} E(T)=212000$ \\
\hline ひずみ硬化勾配 & ${ }_{t} E_{t}\left(\mathrm{~N} / \mathrm{mm}^{2}\right)$ & ${ }_{t} E_{t}(T)=16.4 T+3206$ \\
\hline
\end{tabular}

体)であり、Charpy 衝撃試験の遷移領域を挟むように設定した。実 験により得られた素材の公称応力度一公称ひずみ度関係の代表例を 図 7 に示す。

素材試験での計測項目は、降伏点 ${ }_{n} \sigma_{y}$, 引張強さ ${ }_{n} \sigma_{u}$, 降伏棚のひ ずみ度 $\varepsilon_{y 0}$, ヤング係数 ${ }_{n} E$, ひずみ硬化勾配 $t E_{t}$ である。表 4 , 表 5 に引張試験から評価した各素材特性一温度関係の実験式を示す。な お、SS400については、上位降伏点 ${ }_{n} \sigma_{y 1}$ と下位降伏点 ${ }_{n} \sigma_{y 2}$ の差が明 瞭に現れたため、それぞれ值を計測した。これらの実験式を用いる ことで、既往の実験と同様に応力ひずみ関係をモデル化し、梁部材 の塑性変形能力を予測する。

\section{5 梁フランジ材以外の素材引張試験}

試験体の梁フランジ材以外の部分について JS $-1 \mathrm{~A}$ 号試験片に よる引張試験を行った。試験温度は常温のみである。結果を表 6 に 示す。試験は梁ウェブ, ダイアフラム要素, スキンプレート要素, エ ンドプレート要素である。

表 6 試験体使用鋼材の引張試験結果

\begin{tabular}{|c|c|c|c|c|c|c|}
\hline 試験体 & 部材名 & 材料 & $\begin{array}{c}\text { 降伏点or耐力 } \\
\left(\mathrm{N} / \mathrm{mm}^{2}\right)\end{array}$ & $\begin{array}{c}\text { 引張強さ } \\
\left(\mathrm{N} / \mathrm{mm}^{2}\right)\end{array}$ & 降伏比 & $\begin{array}{c}\text { 破断伸び } \\
(\%)\end{array}$ \\
\hline \multirow{2}{*}{ 490シリーズ } & ダイアフラム & SN490B & 372 & 517 & 0.72 & 29.9 \\
\cline { 2 - 8 } & スキンプレート & SN490B & 363 & 519 & 0.70 & 27.9 \\
\cline { 2 - 8 } & 梁ウェブ & SM490A & 391 & 533 & 0.73 & 26.0 \\
\hline \multirow{2}{*}{ 400シリーズ } & エンドプレート & SM490A & 353 & 514 & 0.70 & 32.3 \\
\cline { 2 - 8 } & 梁ウェブ & SS400 & 311 & 446 & 0.69 & 31.5 \\
\hline
\end{tabular}

\section{3. 試験体の力学的特性予測と加力計画 3.1 試験温度の設定}

試験温度は 2.2 節の Charpy 衝撃試験結果を参考に設定した。低 勒性鋼材を用いた 490 シリーズでは、 NDT 以下から $\mathrm{NDT}+30^{\circ} \mathrm{C}$ 程 度の領域として $-20^{\circ} \mathrm{C}, 0^{\circ} \mathrm{C}, 25^{\circ} \mathrm{C} の 3$ 体とした。これは、既往の実 験 11),12)を参考に、塑性変形能力が予測值を下回る領域から、破壊が 脆性から延性に遷移する境界付近を狙ったものである。

400 シリーズ試験体では、NDT から Charpy 衝撃試験結果のバラ つきが大きいエネルギー遷移温度、 $T_{r E}$ までの領域と、USE に達し た温度とした。設定した試験温度は $-55^{\circ} \mathrm{C},-50^{\circ} \mathrm{C}(2$ 体 $),-45^{\circ} \mathrm{C}$, $-20^{\circ} \mathrm{C}$ の 5 体である。試験体名称は以下のように表記する。

シリーズ 試験温度 記号 (同温度で複数の場合)（例 : 400-50a) $0{ }^{\circ} \mathrm{C}$ 以下の温度管理ではドライアイスを、 $0^{\circ} \mathrm{C}$ ではドライアイスと水 
を、 $25^{\circ} \mathrm{C}$ では水とヒーターをそれぞれ恒温槽に投入し、所定の試験 温度で 1 時間程度安定させた後に加力を開始した。

\section{2 試験体の力学的特性予測}

2.4 節, 2.5 節の素材引張試験結果から試験体の力学的特性を予測 した。降伏モーメント $M_{y}$, 終局モーメント $M_{u}$, 降伏変形角 $\theta_{y}$ の算 出方法を式(3)〜(5)に示す。

式(4)中の $\gamma_{w}$ は梁ウェブの継手効率を考慮した低減係数 15)である。

$$
M_{y}={ }_{n} \sigma_{y f} \cdot Z_{p f}+{ }_{n} \sigma_{y w} \cdot Z_{p w}
$$

$M_{u}={ }_{n} \sigma_{u f} \cdot Z_{p f}+\gamma_{w}{ }_{n} \sigma_{u w} \cdot Z_{p w}$

$\theta_{y}=M_{y}\left(\frac{l}{3 E I_{B}}+\frac{1}{G A_{w} l}\right)$

${ }_{n} \sigma_{y f}:$ フランジ材降伏応力度 $Z_{p f}:$ フランジ塑性断面係数 ${ }_{n} \sigma_{t w}:$ ウェブ材引張強さ ${ }_{n} \sigma_{y w}:$ ウェブ材降伏応力度 $I_{B}:$ 梁断面2次モーメント $G$ : 素材せん断弾性係数

$Z_{p w}:$ ウェブ塑性断面係数 $A_{w}:$ ウェブ断面積

${ }_{n} \sigma_{u f}:$ フランジ材引張強さ

$l:$ 梁部材長さ

$\gamma_{w}:$ 曲げ負担割合低減係数

一般に、スカラップによる断面欠損と柱スキンプレート面外変形 が継手効率の低下要因となる。既往の実験では H 形断面梁一角形鋼 管柱接合部を模擬した試験体を用いたため、柱スキンプレート面外 変形による継手効率低下を考慮する必要があった。本実験では、梁 ウェブを、断面に余裕がある固定梁やエンドプレートに接合してい るため、 $\gamma_{W}$ の算定ではスカラップによる断面欠損のみを考慮した。

予測に用いた素材強度は、梁フランジ材で 2.4 節表 4 , 表 5 の素 材特性温度補正式より算出した。400 シリーズの梁フランジ材の降 伏点には下降伏点 ${ }_{n} \sigma_{92}$ を用いた。梁ウェブについては表 6 の素材引 張試験結果を用いた。予測結果を表 7 に示す。

表 7 試験体梁の力学的特性予測值

\begin{tabular}{|c|c|c|c|c|}
\hline 試験体 & $\begin{array}{c}K_{e} \\
(\mathrm{kN} . \mathrm{m} / \mathrm{rad})\end{array}$ & $\begin{array}{c}M_{y} \\
(\mathrm{kN} . \mathrm{m})\end{array}$ & $\begin{array}{c}\theta_{y} \\
(\mathrm{rad})\end{array}$ & $\begin{array}{c}M_{u} \\
(\mathrm{kN} . \mathrm{m})\end{array}$ \\
\hline $490+25$ & $5.21 \times 10^{4}$ & 529.6 & $1.04 \times 10^{-2}$ & 774.8 \\
\hline $490-0$ & $5.21 \times 10^{4}$ & 543.5 & $1.05 \times 10^{-2}$ & 800.8 \\
\hline $490-20$ & $5.21 \times 10^{4}$ & 554.4 & $1.06 \times 10^{-2}$ & 821.4 \\
\hline $400-20$ & $5.13 \times 10^{4}$ & 353.0 & $6.88 \times 10^{-3}$ & 445.7 \\
\hline $400-45$ & $5.13 \times 10^{4}$ & 370.7 & $7.23 \times 10^{-3}$ & 464.1 \\
\hline $400-50$ & $5.13 \times 10^{4}$ & 374.2 & $7.29 \times 10^{-3}$ & 467.8 \\
\hline $400-55$ & $5.13 \times 10^{4}$ & 377.7 & $7.36 \times 10^{-3}$ & 471.5 \\
\hline
\end{tabular}

\section{3 試験体の塑性変形能力}

鋼部材の塑性変形能力に影響を与える要因として降伏比 $Y . R$ と、 部材降伏後の 2 次剛性がある。熱間成形された板要素で構成された 部材の 2 次剛性は、弾性剛性に対する比率を $k_{p}$ として一般的に式(6) の関係にあるとされる ${ }^{18)}$

$$
k_{p}=0.03+0.04|n|
$$

$n$ : 軸力比

式(6)の関係を利用し、部材の $M-\theta$ 関係を図 8 のような bi-linner モデルに簡略化することで、略算的に累積塑性変形倍率 $\eta$ を予測す ることができる。梁部材の場合は軸力 0 であるため、 $k_{p}=0.03(3 \%)$ となり、累積塑性変形倍率 $\eta$ は式(7)で表せると言われている ${ }^{19) 。}$

$$
\eta=\frac{M_{u}-M_{y}}{k_{p} \cdot K_{e}} \cdot \frac{1}{\theta_{y}}=\frac{M_{u}-M_{y}}{0.03 K_{e}} \cdot \frac{1}{\theta_{y}}
$$

ここで累積塑性変形倍率 $\eta$ は、降伏変形角 $\theta_{y}$ と終局変形角 $\theta_{u}$ を

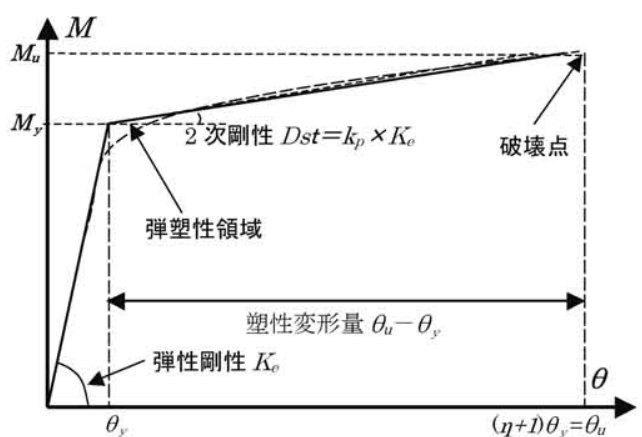

図 $8 M-\theta$ 関係の bi-linner 置換モデル
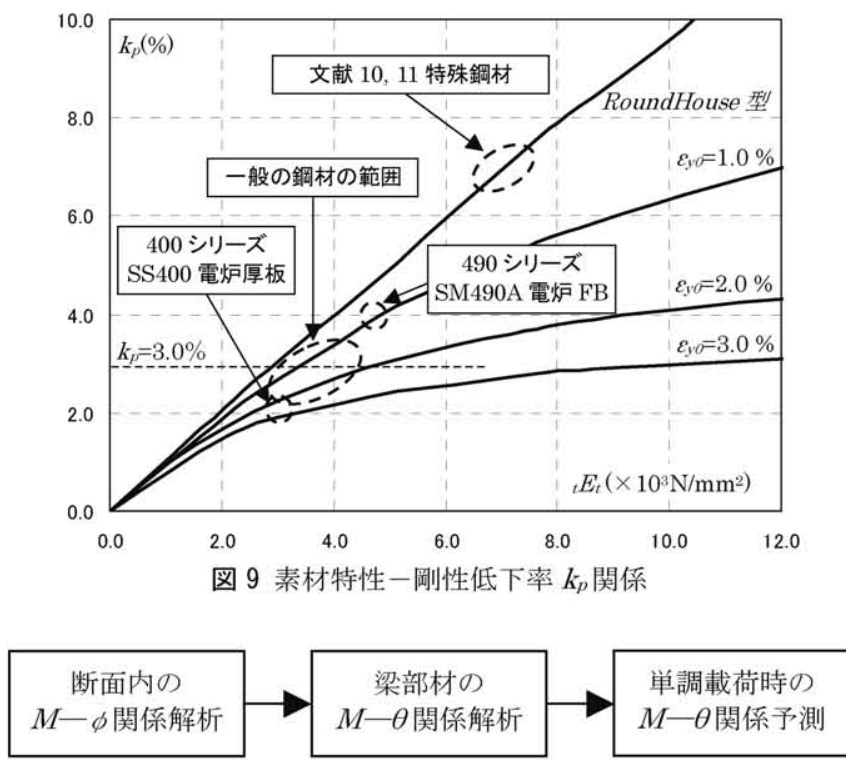

図 10 CDC 解析法の概念

用いて式(8)のように表せる。式(8)の関係を式(7)に代入することで 部材の終局変形量 $\theta_{u}$ を式(9)のように略算することができる。

$$
\begin{aligned}
& \eta=\theta_{u} / \theta_{y}-1 \\
& \theta_{u}=\frac{M_{u}-M_{y}}{k_{p} \cdot K_{e}}+\theta_{y}
\end{aligned}
$$

しかし $k_{p}$ の值は素材の応力度一ひずみ度関倸の影響を受け、 RoundHouse 型に近い性質を示寸鋼材を用いた既往の実験 10),11),13 では $k_{p}=0.06 \sim 0.07$ 程度の值を示した。そこで、一般的な鋼部材に おける $k_{p}$ と応力度一ひずみ度関係を検討した。検討は、CDC 解析 ${ }^{(2}{ }^{6}$ により、各素材モデルの $\varepsilon_{y 0}$ と ${ }_{t} E_{t}$ をパラメータとして算出し、 図 9 のように整理した。CDC 解析法の概念を図 10 に示す。図 9 の 縦軸は $k_{p}$ を、横軸はひずみ硬化勾配 $t E_{t}$ を表す。また降伏棚のひず み度 $\varepsilon_{y 0}$, を設定し、降伏棚のない RoundHouse 型から $\varepsilon_{y 0}=3 \%$ の範 囲で関係を求めた。素材の降伏比は一般的な值として $70 \%$ (本論の 素材は 66 〜2\%)で計算した。

2.4 節の素材引張試験結果から、図 9 を用いて試験体の $k_{p}$ を算出 すると、 490 シリーズでは 0.04 程度、 400 シリーズでは 0.02 程度 $\mathrm{d}$ である。よって各試験体の終局変形角 $\theta_{u}$ は、 490 シリーズで $0.13 \mathrm{rad}$, 400 シリーズで 0.094rad となった。

\section{4 加力計画}

加力は降伏変形角 $\theta_{y}$ を基準とした漸増変位振幅による正負交番 

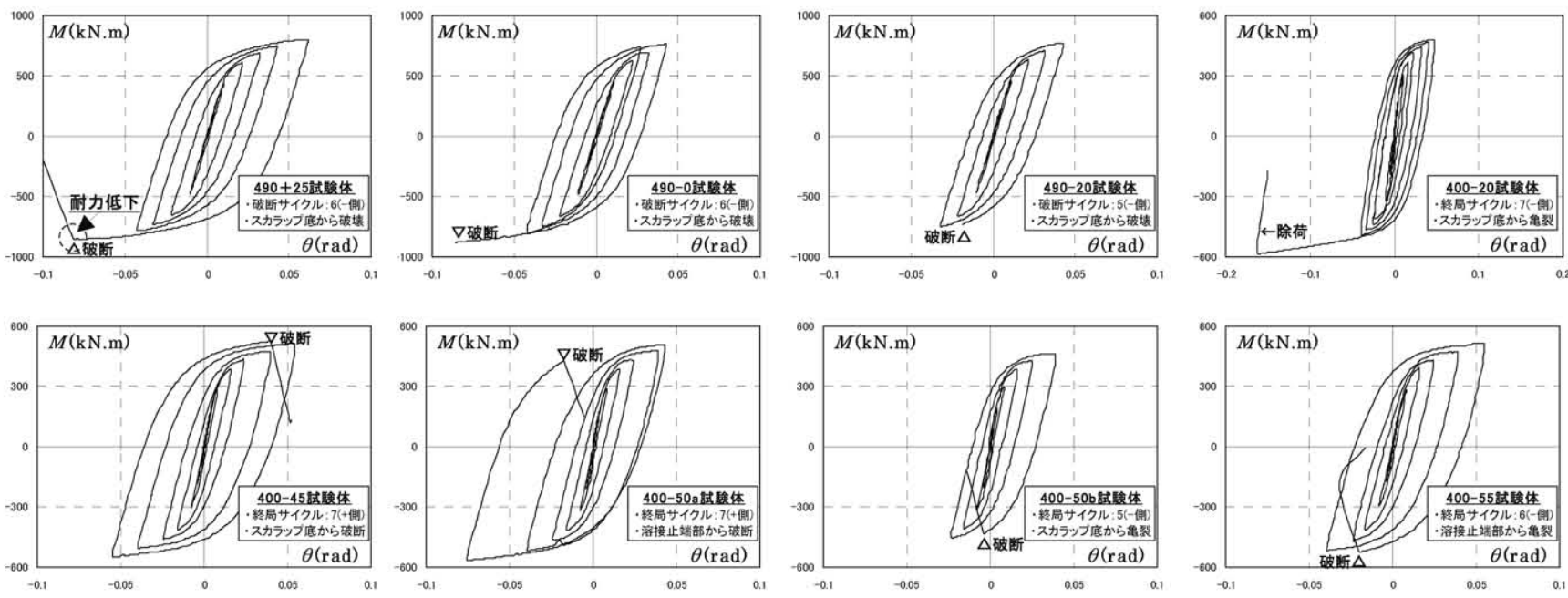

図 11 梁端モーメント $M$-梁部材角 $\theta$ 関係と試験体の終局状態

繰り返し載荷とした。最初に基準値の \pm 0.5 倍の加力を行って、加 力装置や試験計測装置の確認を行う。その後、 \pm 1 倍間隔を基準に 破断まで加力を行う。

しかし 400 シリーズの極低温試験体 $\left(-45^{\circ} \mathrm{C}\right.$ 以下 $)$ では、泠却装置 の都合上、保温可能時間が限られているため、加力サイクルを \pm 0.5 倍, \pm 1 倍, \pm 2 倍, \pm 3 倍, \pm 5 倍, \pm 7 倍， \pm 10 倍とサイクルを一 部省略し、加力時間を短縮した。また、試験体の変形状況から、最 終サイクルで加力サイクルを変更することもあった。

\section{4. 実験結果}

\section{1 荷重一変形関係と試験体終局状態}

実験により得られた荷重変形関係は、接合部のモーメント荷重 $M$ と、変形を梁の部材角 $\theta$ に置換した值を用いた。各試験体の $M-\theta$ 関係を図 11 に示す。

490 シリーズ試験体では、 $490+25,490-0$ 試験体で 6 サイクル 目の一側で、490-20試験体では 5 サイクル目の負側で破断した。 $490+25$ 試験体では、破断直前にわずかな耐力低下が見られた。 $490+25$ 試験体は、わずかな耐力低下があることから、破壊が延性 に遷移する境界にあると推測できる。490-0, 490-20 試験体では 耐力低下は見られず、荷重変形関係からも脆性的な性質の破壊であ ると推測できた。破壊は、全ての試験体でスカラップ底を起点とし て発生し、梁フランジ母材に伝播していた。破壊直後の試験体の状 況から、3 体全てに脆性的な破面が見られたが、試験体から切り出 した破断面の観察から、490+25 試験体で破壊起点となった初期亀 裂の成長量が大きかった。

400-20 試験体は、終局状態で横座屈が発生し、スカラップ底に 明瞭な延性亀裂が生じたことでほぼ耐力上昇がなくなったことから、 破断する前に加力を停止した。400-45 試験体では 7 サイクル目の +側でスカラップ底から破断し、400-50a 試験体では 7 サイクル 目の+側で溶接止端部から破断した。 $400-50 \mathrm{~b}$ 試験体では 5 サイ クル目の一側でスカラップ底から亀裂が生じ、400-55 試験体では 6 サイクル目の一側で溶接止端部から亀裂が生じた。ただし実験後 に切り出した破断面観察から、溶接部破断の試験体でも脆性亀裂の 起点は母材側だった。荷重一変形関係からすべての試験体で、ある

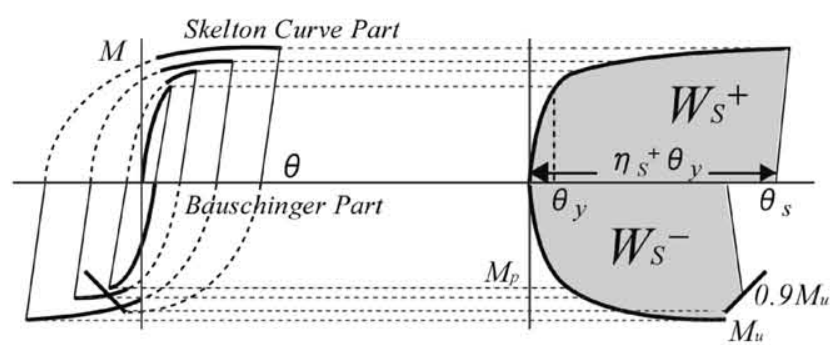

図 12 骨格曲線の作成方法

程度塑性変形した後に破断していることがわかる。 また、400 シリーズでは、 $-45^{\circ} \mathrm{C}$ 以下の試験体では破断する直前 に耐力低下がみられなかったことと、実験後の梁端部の様子から脆 性的な破壊であったと判断できる。

\section{2 骨格曲線の抽出と予測値との比較}

図 11 に示す各試験体の $M-\theta$ 関係から、新しい荷重領域のみを つなぎ合せ、骨格曲線を作成する。骨格曲線は、一方向載荷時の荷 重変形関係に置換できるため 20)、加力サイクルの異なる実験結果を 定量的に比較することができる。荷重一変形関係から骨格曲線を作 成する方法を図 12 に示す。

作成した骨格曲線を図 13 に示す。図 13 中には CDC 解析法によ り予測した一方向載荷時の $M-\theta$ 関係も追記している。なお、400 -20 試験体のみ横軸の縮尺が異なる。結果から、すべての試験体で 降伏後の荷重一変形関係が予測值より大きい傾向があり、逆に $M$ 以下の弾塑性領域では予測值以下の值を示した。弾塑性領域で早期 に非線形性を示すのは、既往の研究から梁ウェブの継手効率低下の 影響と言われている。本試験体ではスカラップによる断面欠損が大 きいため、この影響が荷重変形関係に現れたと考えられる。

延性破壊と判断した $490+25$ 試験体と 400-20 試験体では、予 測值を上回る変形能力を示したことがわかる。また脆性的な性質を 示した 400-45, 400-50a 試験体でも予測值を若干上回る変形能力 を示した。早期に破断した 490-20,400-50b 試験体では、予測値 の半分以下の変形能力となり、耐力も予測值以下のレベルとなった。

\section{3 実験結果の評価}

表 8 に各試験体の $M-\theta$ 関係と骨格曲線から評価した実験值を、 

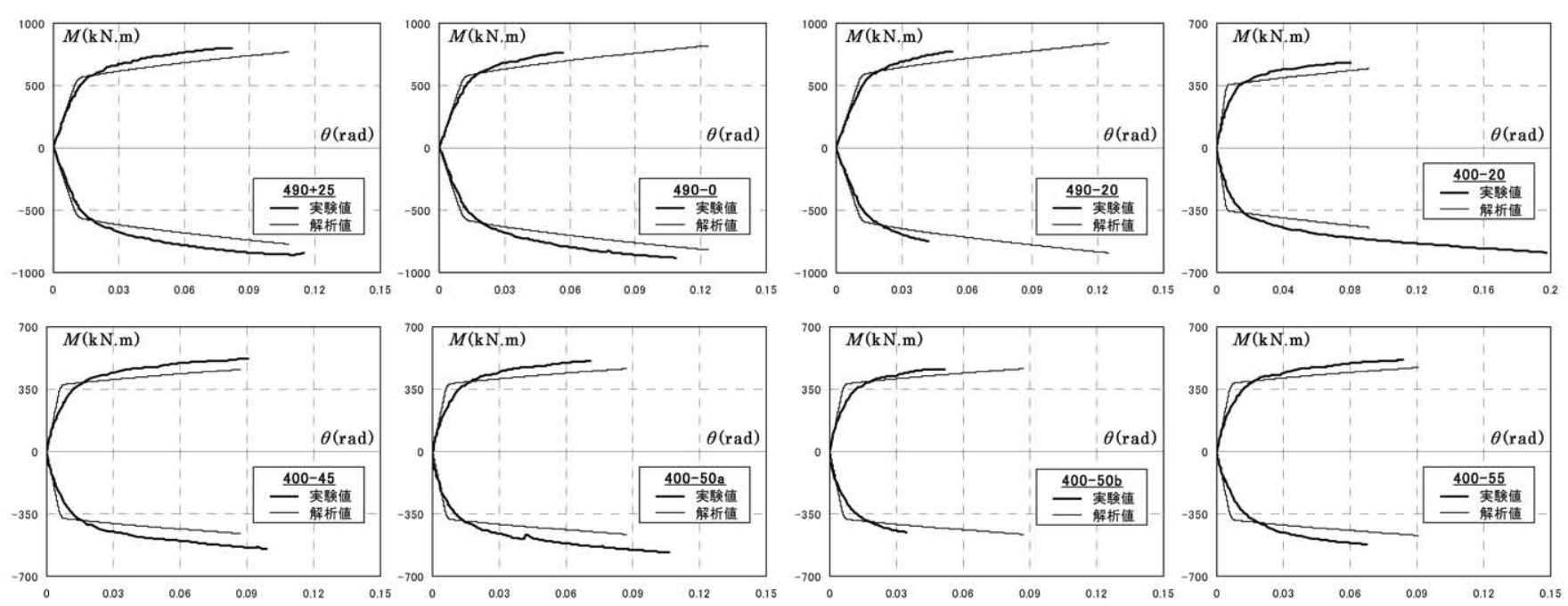

図 13 各試験体の骨格曲線

表 8 実験の評価値

\begin{tabular}{|c|c|c|c|c|c|c|c|c|c|c|c|c|}
\hline 試験体 & 加力方向 & \begin{tabular}{|c|}
$K_{e}{ }^{\prime}$ \\
$(\mathrm{kN} \cdot \mathrm{m} / \mathrm{rad})$
\end{tabular} & $\begin{array}{c}M_{y}{ }^{\prime} \\
\text { (kN.m) }\end{array}$ & $\begin{array}{c}\theta_{y}^{\prime} \\
\left(10^{-2} \mathrm{rad}\right)\end{array}$ & $\begin{array}{c}M_{u}{ }^{\prime} \\
\text { (kN.m) }\end{array}$ & $\begin{array}{c}\theta_{\max } \\
\left(10^{-2} \mathrm{rad}\right)\end{array}$ & $\begin{array}{c}\theta_{s} \\
\left(10^{-2} \mathrm{rad}\right) \\
\end{array}$ & $a$ & $\eta_{s}$ & $\begin{array}{c}W_{p} \\
\text { (kN.m) }\end{array}$ & $\begin{array}{c}{ }_{s} W_{p} \\
(\mathrm{kN} . \mathrm{m})\end{array}$ & 破壊形式 \\
\hline \multirow[t]{2}{*}{$490+25$} & + & $4.59 \times 10^{4}$ & 581 & 1.75 & 801 & 6.15 & 8.20 & 1.38 & 3.7 & 91 & 46 & 延性 \\
\hline & - & & 588 & 1.85 & 856 & 8.14 & 11.50 & 1.46 & 5.2 & 138 & 74 & \\
\hline \multirow[t]{2}{*}{$490-0$} & + & $4.62 \times 10^{4}$ & 578 & 1.65 & 766 & 4.28 & 5.66 & 1.33 & 2.4 & 68 & 27 & 脆性 \\
\hline & - & & 594 & 1.91 & 882 & 8.60 & 10.80 & 1.48 & 4.7 & 123 & 69 & \\
\hline \multirow[t]{2}{*}{$490-20$} & + & $4.62 \times 10^{4}$ & 590 & 1.67 & 773 & 4.27 & 5.34 & 1.31 & 2.2 & 45 & 25 & 脆性 \\
\hline & - & & 569 & 1.62 & 747 & 3.21 & 4.23 & 1.31 & 1.6 & 43 & 17 & \\
\hline \multirow[t]{2}{*}{$400-20$} & + & $4.52 \times 10^{4}$ & 319 & 1.06 & 481 & 4.80 & 7.99 & 1.51 & 6.5 & 63 & 29 & 延性 \\
\hline & - & & 333 & 1.30 & 587 & 16.34 & 19.70 & 1.76 & 14.2 & 139 & 93 & \\
\hline \multirow[t]{2}{*}{$400-45$} & + & $4.37 \times 10^{4}$ & 357 & 1.10 & 523 & 5.44 & 9.07 & 1.46 & 7.2 & 79 & 37 & 脆性 \\
\hline & - & & 357 & 1.25 & 546 & 5.48 & 9.91 & 1.53 & 6.9 & 70 & 42 & \\
\hline \multirow[t]{2}{*}{$400-50 a$} & + & $4.57 \times 10^{4}$ & 347 & 1.11 & 508 & 4.28 & 7.08 & 1.47 & 5.4 & 55 & 27 & 脆性 \\
\hline & - & & 374 & 1.24 & 560 & 7.56 & 10.60 & 1.50 & 7.5 & 76 & 46 & \\
\hline \multirow[t]{2}{*}{$400-50 \mathrm{~b}$} & + & $4.73 \times 10^{4}$ & 332 & 0.98 & 463 & 3.87 & 5.15 & 1.40 & 4.3 & 26 & 18 & 脆性 \\
\hline & - & & 316 & 0.95 & 453 & 2.35 & 3.43 & 1.43 & 2.6 & 21 & 10 & \\
\hline \multirow[t]{2}{*}{$400-55$} & + & $4.45 \times 10^{4}$ & 355 & 1.15 & 513 & 5.50 & 8.35 & 1.44 & 6.3 & 53 & 33 & 脆性 \\
\hline & - & & 335 & 1.18 & 524 & 3.95 & 6.75 & 1.56 & 4.7 & 55 & 25 & \\
\hline
\end{tabular}

$K_{e}{ }^{`}$ : 弾性載荷時の実測弾性剛性 $\quad \theta_{\max }$ ：履歷曲線上における最大部材角

$M_{y}{ }^{\prime}$ : 梁端全塑性モーメント $\quad \theta_{s}$ ：骨格曲線における最大部材角

$W_{p} \quad$ : 全履歴における吸収エネルギー量

$\theta_{y}{ }^{\prime}: M_{y}^{\prime}$ に対応寸る弾性限部材角

$\alpha \quad$ : 耐力上昇率 $\left(M_{u}{ }^{-} / M_{y}{ }^{\prime}\right)$

$M_{u}^{\prime}$ : 梁端最大モーメント

$\eta_{s} \quad$ : 骨格曲線における累積塑性変形倍率
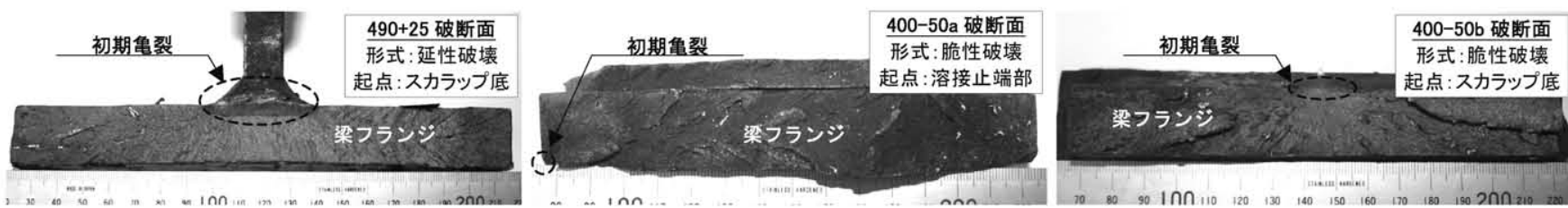

図 14 梁フランジ破断面(代表例)

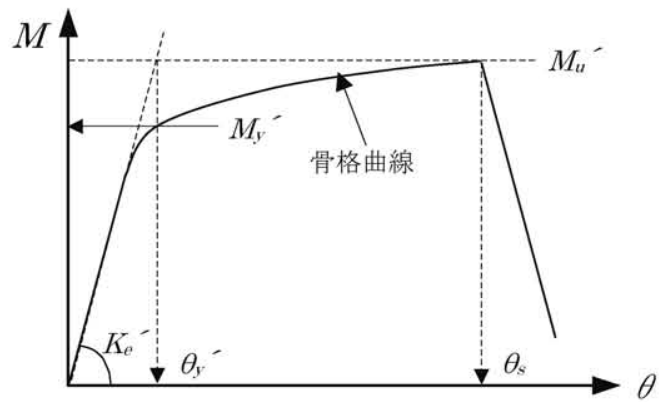

図 15 General-Yield 法による評価

図 14 は破断した梁フランジの破断面(代表例)を示す。表 8 中の $M_{y}^{\prime}$, $\theta_{y}{ }^{\prime}$ は骨格曲線から General-Yield 法21を用いて算出した值である。 General-Yield 法による評価方法を図 15 に示す。脆性破壊と延性破 壊の判断は荷重変形関係における耐力低下の有無、実験時に観察し た梁端部の亀裂状態、破断後の破断面の延性亀裂深さ7から総合的 に判断した。なお、非破断だった 400-20 試験体については破断面 による判断ができなかったため、載荷時に明瞭な延性亀裂がスカラ ップ底に生じたことを考慮し、延性破壊と判断した。

結果から、試験温度の低下とともに終局モーメント $M_{u}^{\prime}$ や、塑性 


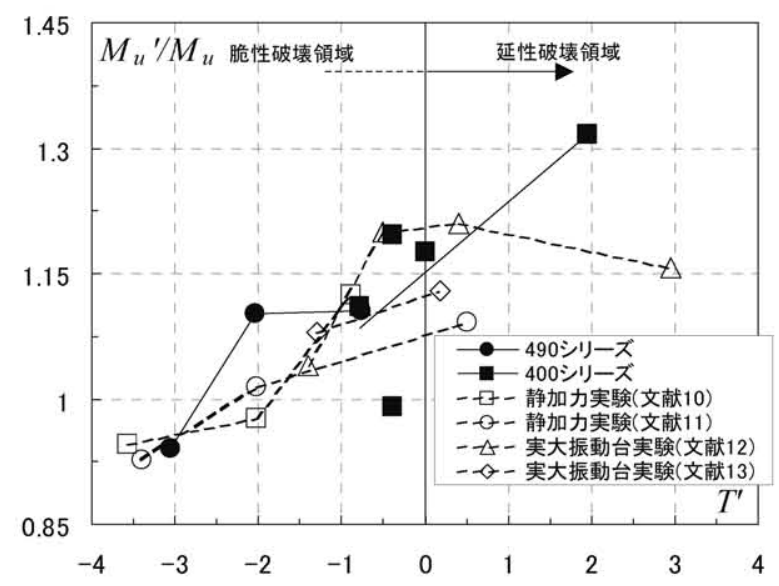

図 16 最大耐力比一基淮化温度 $T^{\prime}$ 関係

変形能力を示す $\theta_{s}, \eta s, s W p$ が低下していく傾向が見られた。また、 400 シリーズでは、490 シリーズと比較して耐力上昇率 $\alpha$ が高い傾 向が見られた。これは 400 シリーズの方が部材降伏後の変形能力が 高いことを示している。490 シリーズと 400 シリーズでの変形能力 の差は $\eta_{s}$ にも見られ、延性破壊した 490 シリーズの $\eta_{s}$ は 5.2 なの に対し、400 シリーズでは 14.2 となった。

\section{5. 基準化温度 $T^{\prime}$ を用いた耐力評価}

松本らの研究 13)では、Charpy 衝撃試験のエネルギー遷移曲線の 形状を実験結果に反映する手法として、基準化温度 $T^{\prime}$ を定義して いる。基準化温度は、式(1)のエネルギー遷移曲線の指数部分の值に 注目したもので、式(10)のように表される。

$$
T^{\prime}=a \cdot\left(T-{ }_{v} T_{r E}\right)
$$

つまり基準化温度は、エネルギー遷移温度 ${ }_{v} T_{r E}$ に対する実験結果 の相対的な位置関係を、エネルギー遷移曲線の形状を表す定数 $a$ で

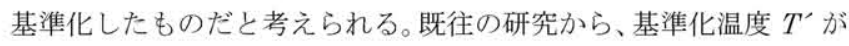
-1.0 から 0 の間で破壊が脆性から延性に遷移し、最大耐力や塑性 変形能力が上限に達する傾向が見られた。なお、本論で基淮化温度 算出に用いた Charpy 衝撃試験結果は、脆性亀裂が母材から発生し ていることから、梁フランジ母材の值を用いた。

図 16 に基準化温度 $T^{\prime}$ 一最大耐力比関係を示す。最大耐力比は、 実測值の梁端終局モーメント $M_{u}$ 一、式(4)による梁ウェブの継手 効率を考慮した梁端終局モーメントの予測值 $M_{u}$ で除した無次元量 である。

図 16 中には、○で示す 490 シリーズ試験体、で示す 400 シリ 一ズ試験体の評価値に加え、既往の静的加力実験、実大振動台実験 の結果も載せている。脆性破壊となる基準化温度 $T^{\prime} か ゙-1 ０$ 以下 の領域では、試験体によらずほぼ同一の傾向を示している。しかし、 490-0 試験体では高い值となり、また 400-55b 試験体では、基準 化温度が 0 に近いにもかかわらず最大耐力比が 1.0 を下回った。脆 性破壊領域では最大耐力比の值が安定しない傾向が見られる。

また基準化温度 $T^{\prime}$ が 0 以上の延性破壊領域では 400-20 試験体 で最大耐力比が 1.3 程度まで上昇した。これは、 $490+25$ 試験体や 既往の実験結果の延性破壊時における最大耐力比の上限と比較して も高い值である。

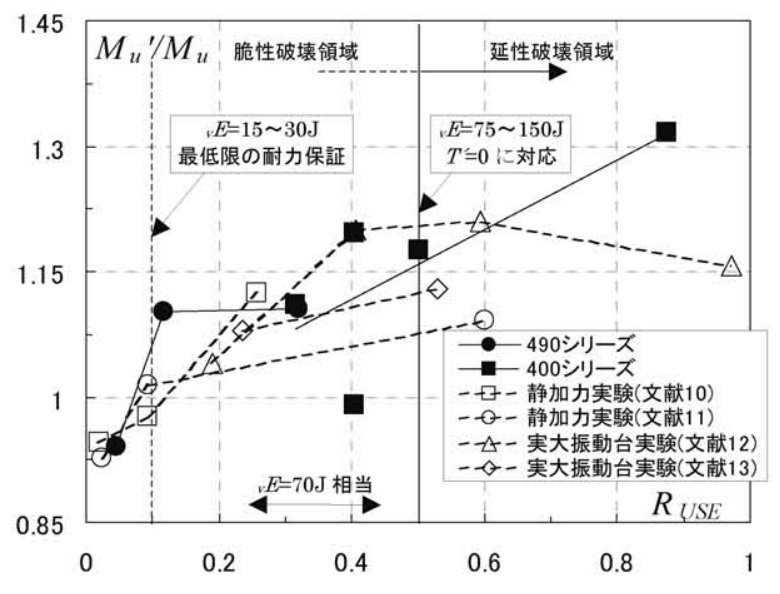

図 17 最大耐力比一USE 比 関係

\section{6. 上部棚吸収エネルギーUSEに注目した耐力評価}

Charpy 衝撃試験により得られる素材固有の特性を表す值として、 上部棚吸収エネルギー(USE: Upper Shelf Energy)が挙げられる。 USE は Charpy 衝撃試験における、脆性破面率がほぼ $0 \%$ となった 時点での吸収エネルギー量を表すもので、比較的簡便な操作で知る ことができる。

\section{1 USE 比による最大耐力評価}

USE 值を利用した評価手法として、USE 比を定義し、本実験と 既往の実験を比較した。USE 比 $R_{U S E}$ の定義を式(11)に示す。また、 遷移曲線を利用した $R_{U S E}$ の算出には式(12)を用いる。

$$
\begin{aligned}
& R_{U S E}={ }_{v} E /{ }_{v} E_{U S E} \\
& R_{U S E}=\frac{1}{\exp \left\{-a\left(T-{ }_{v} T_{r E}\right)\right\}+1}
\end{aligned}
$$

式(11)、式(12)から、USE 比 $R_{U S E}$ は Charpy 吸収エネルギーの遷 移領域における、各温度の試験結果の相対位置を表す量である。 Charpy 吸収エネルギー遷移の相対的な位置関係に注目していると いう観点から、5 節で示した基準化温度と類似した評価方法だとい える。式(10)に示寸基準化温度の定義から、吸収エネルギー遷移温 度 ${ }_{v} T_{r E}$ に対応する温度を $T^{\prime}=0$ としている。吸収エネルギー遷移温 度 ${ }_{v} T_{r E}$ における吸収エネルギー ${ }_{v} E$ は USE の 0.5 倍であるため、 $T^{\prime}=0$ は USE 比 $R_{U S E}=0.5$ に対応する。基準化温度 $T^{\prime}$ の算定には、 Charpy 衝撃試験結果のフルカーブを必要とするが、USE 比を利用 した評価では、必ずしも遷移曲線のフルカーブを必要としない。

図 17 に最大耐力比-USE 比関係を示寸。評価結果から、図 16 で示す最大耐力比一基準化温度関係と、ほぼ同等の分布傾向を示し た。評価結果から、R RUSE が 0.1 を下回る領域では、最大耐力比が 1.0 を下回り、予測レベルの最大耐力を満足していないことがわかる。 既往の実験結果 22 , 23)なとを参考にすると、 $R_{U S E}=0.1$ に対応する Charpy 吸収エネルギー(圧延方向)は $15 \sim 30 \mathrm{~J}$ となり、造船分野の 脆性破壊回避条件 5)である $、 E=10 \sim 20 \mathrm{ft}-1 \mathrm{~b}(13 \sim 27 \mathrm{~J})$ と概㸚対応す る。ただし、490-0 試験体のように $R_{U S E}$ が 0.1 程度であっても、 最大耐力比が試験体の上限に達寸るケースも見られた。

$R_{U S E}$ が 0.5 までの領域では、 $R_{U S E}$ の増加とともに最大耐力が上昇 する傾向が見られ、0.25 0.5 の領域で破壊が延性に遷移する現象 が見られた。ただし $400-50 \mathrm{~b}$ 試験体のように $R_{U S E}$ が 0.4 程度と 


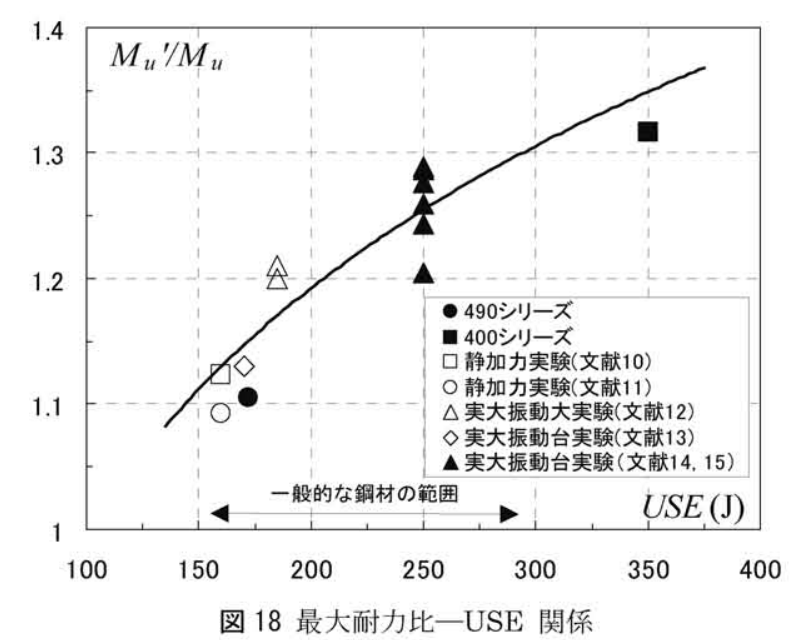

高い值を示しながら、脆性破壊し、最大耐力比が 1.0 を下回るケー スも見られた。 $R_{U S E}$ が 0.5 を上回る領域では破壊が延性に遷移し、 最大耐力比も上限に達する傾向が見られた。このことから、USE 比 は、Charpy 吸収エネルギーのデータから脆性破壊への遷移を直接 的に評価できるパラメータと言える。

以上の考察から、USE 比 $R_{U S E}$ を用いた評価は基準化温度 $T^{\prime}$ と 同様に、試験体によらず部材耐力を同列に評価・検討できる指標で あることが確認できた。また、基準化温度を用いた評価と同様に、 脆性破壊領域( $R_{U S E}$ が $0.25 \sim 0.5$ 以下の領域)では、最大耐力比が安 定しないケースも見られた。

\section{2 USE 值を用いた終局耐力余裕度の検討}

本実験や既往の実験から、破壊が延性破壊に遷移寸ると最大耐力 が上限に達する傾向が見られ、それらの耐力上限值は、予測值の $10 \%$ から $30 \%$ 程度高い值を示した。延性破壊は鋼素材が保有する強 度を十分に発揮した破壊であるため、耐力上限は部材の保有する性 能を表す值であると解釈することができる。

構造物の設計では、予測耐力を保証する必要があるが、予測に対 する余裕度(最大耐力比が 1.0 を超える領域)は、想定を超える地震 力等での破壞を防ぐ上でも重要である。ゆえに、最大耐力に対する 余裕度を定量的に判断する必要がある。

本論では、最大耐力予測值に対寸る余裕度を評価するにあたって、 素材の上部棚吸収エネルギーUSEに注目した。図 18 に最大耐力比 -USE 関係を示す。図 18 には本論の 490 シリーズ, 400 シリーズ 試験体に加えて、比較対象として既往の実大実験結果 10) 15)を追加 した。実験データの選択には、梁フランジ, 梁ウェブの接合条件が 本論と類似するもの、Charpy 衝撃試験の遷移曲線が得られている もの、梁ウェブの継手効率や素材特性の温度依存性を考虑した予測 終局モーメントが算出可能なものとした。脆性破壊した試験体があ る文献については、延性破壊した試験体のみを抽出している。延性 破壊の判別には耐力低下があること、もしくは破断面に明瞭な延性 亀裂が成長していることを条件 7とした。

図 18 から、USE が 160J 程度の試験体では最大耐力比が 1.1 程 度となり、予測值に対する余裕度は+ $10 \%$ となった。USE が $250 \mathrm{~J}$ の試験体では、最大耐力比 1.2 から 1.3 程度、USE が $350 \mathrm{~J}$ の本論 400-20 試験体では最大耐力比が 1.3 を上回った。結果から、USE が高い素材を用いることで、部材の終局耐力上限值も上昇する傾向
が見られた。

最大耐力の上限を高めることは、部材の塑性変形能力を高めるこ とにもつながり、引いては部材のエネルギー吸収能力を高めること にもつながる。素材の USE は耐震設計上の意味があること示寸結 果と言える。

\section{7. まとめ}

本論では、Charpy 衝撃試験の特性が異なる 2 種類の鋼材(低勒性 SM490A 電炉平鋼, 高勒性 SS400 電炉厚板)を用いて、実大静加力 実験を行った。得られた実験結果の部材耐力に注目し、Charpy 衝 撃試験結果との対応性を検討し、既往の実大実験と比較した。これ により得られた知見を以下に示す。

1）実験結果から、試験温度の上昇とともに終局耐力も上昇する傾向 が見られた。また、延性破壊と評価された試験体では、予測值を上 回る終局耐力と変形能力を示した。

2）既往の実験でも用いられた基準化温度による最大耐力評価では、 試験体構成材料によらずほぼ同一の傾向を示した。遷移曲線上の相 対的な位置関倸に注目した基準化温度は、部材の耐力評価を行う上 で有用といえる。

3）脆性破壊した試験体でも、終局耐力の予測值を上回るものが見ら れた。しかし、最大耐力ー基準化温度関係から、脆性破壊領域では 耐力のバラつきが見られた。特に同じ試験温度である $400-50 \mathrm{a}$, 400- $50 \mathrm{~b}$ 試験体では耐力，破壊起点が異なる結果が示された。この ような脆性破壊領域におけるバラつきについては、未だに不明瞭な 点が多いため、更なる検討が必要と言える。

4）基淮化温度と同様に、Charpy 衝撃試験のエネルギー遷移曲線に 対する実験結果の相対的な位置関係に注目した指標として、簡便に 評価できる USE 比を定義し、試験体終局耐力の検討を行った。検 討結果は次の 4 項目にまとめられる。

・ USE 比 RUSE が 0.1 を下回る領域では、試験体は脆性破壊し、 最大耐力も予測值を下回った。また、 $R_{U S E}=0.1$ は造船分野 で提唱された脆性破壊回避条件に概ね対応する。

・ USE 比 $R_{U S E}$ が 0.5 までの領域では、最大耐力が上昇する傾 向が見られ、 $R_{U S E}$ が $0.25 \sim 0.5$ の領域で破壊が脆性から延性 に遷移する現象が見られた。

・ 脆性破壊した試験体では、 $R_{U S E}=0.4$ 程度でも予測值を下回 る耐力で破壊したケースが見られた。

. 基準化温度と同梯に、USE 比を用いて脆性破壊一延性破壊 領域での最大耐力の変化を表すことができる。

5）素材の上部棚吸収エネルギーUSE を用い、部材終局耐力の予測 值に対する余裕度を検討した。本実験と既往の実験のデータを比較 した結果、USE 值が高い素材を用いることで、延性破壊時の最大耐 力の余裕度が高まる傾向が示された。

本論では Charpy 吸収エネルギー遷移曲線および、Charpy 衝撃 試験から簡便に評価できる上部棚吸収エネルギーUSE が、部材耐力 の評価に有用である可能性が示された。今後は、脆性破壊領域の而 力のバラつきも含め、簡便かつ信頼できる部材耐力の評価手法の検 討を行っていきたい。 


\section{謝辞}

本研究は平成 20 年度日本鉄鋼連盟研究助成を受けた。試験体製 作には那須電機鉄工(株)に協力を得た。関係各位の協力に感謝する。

参考文献

1）加藤勉, 森田耕次 : 極厚鋼部材の脆性破壊, 日本建築学会論文報告集, No.156, pp.1•10, 1968.2

2) 加藤勉, 森田耕次, 橋本健一: 極厚鋼部材の脆性破壊(その 2), 日本建築 学会論文報告集, No.176, pp.11·16, 1970.10

3）竹波正洪, 斎藤辰彦, 田中淳夫, 榎本憲正: 極厚 $\mathrm{H}$ 形鋼を用いた鋼構造 柱はり接合部の力学的性状に関する実験的研究, 日本建築学会論文報 告集, No.210, pp.23-32, 1973.8

4) 日本鋼構造協会 : 兵庫県南部地震鋼構造被害調查報告, JSSC テクニカ ルレポート, 1997.2

5) 今井保穂 : 鋼材の $\mathrm{V}$ シヤルビ試験と落重試験, 造船協会誌, No.369, pp252-257, 1960.6

6）鉄骨梁端溶接接合部の脆性的破断防止ガイドライン・同解説，日本建築 センター, 2003.9

7）松本由香: 既往の実験データに基づく梁端断面性能及び変形性能の評価, 日本建築学会 シンポジウム 鋼構造柱梁接合部の破壊に対する最新の 評価法, pp3-19, 2005.11

8）日本電気協会 原子力規格委員会 : 原子力発電所用機器に対寸る破壞勒 性の確認試験方法 JEAC4206-2007, 2008.6

9）日本電気協会 原子力規格委員会 : 原子炉構造材の監視試験方法 JEAC 4201-2007, 2008.6

10）岩佐州紘, 新井佑一郎, 半貫敏夫, 秋山宏 : 実大鋼構造柱梁接合部の延 性破壊一脆性破壊遷移実験, 日本鋼構造協会 鋼構造論文集, No.50, pp $45 \cdot 56,2006.6$

11）新井佑一郎, 半貫敏夫, 秋山宏 : 従来型スカラップ工法による実大鋼構 造柱梁接合部の延性破壊一脆性破壞遷移実験, 日本建築学会構造系論 文集, No.631, pp.1649-1657, 2008.9

12）秋山宏, 山田哲, 松本由香, 松岡三郎, 大竹章夫, 杉本浩一: 実大柱梁接 合部の試験温度による延性破壊一脆性破壊遷移, 日本建築学会構造系 論文集, No.522, pp.105•112, 1999.8

13）松本由香, 山田哲, 岡田健, 井出匡俊, 竹内徹, 竹内悦男, 小川信行, 秋 山宏: 実大振動台実験における鋼構造柱梁接合部の破壊性状と変形能力 評価, 日本建築学会構造系論文集, No.560, pp.181·188, 2002.10

14）秋山 宏，山田 哲，松本由香，松岡三郎，小倉桂治，北村春幸：実大 振動台実験による柱梁接合部の破壊性状に関寸る研究, 日本建築学会 構造系論文集, No.512, pp.165 - 172, 1998.10

15）松本由香, 秋山宏, 山田哲：鋼構造柱梁接合部における梁の変形能力と ウェプの継手効率, 日本建築学会構造系論文集, No.523, pp.117·124, 1999.9

16）新井佑一郎，小中孔明，半貫敏夫，秋山宏 : 実大鋼構造柱梁接合部の延 性破壊·脆性破壊遷移実験 その 5 単純化構造モデルによる実大試験概 要, 日本建築学会大会学術講演梗概集 2008 (中国), C·1,p.1047·1048, 2008.8

17）鋼構造接合部の力学性状に関する研究の現状, 日本建築学会, pp124 $184,1993.10$

18）秋山宏 : 建築物の耐震極限設計, 東京大学出版会, 1980

19）秋山宏, 山田哲: 兵庫県南部地震における鋼構造剛接骨組の耐震性評価, 日本建築学会構造系論文集, No.501, pp.151·157, 1997.11

20) 加藤勉, 秋山宏 : 構造部材の耐力(その 4), 日本建築学会論文報告集, No.151, pp.15·20, 1968.9

21）独立行政法人 建築研究所、社団法人 日本鉄鋼連盟 : 鋼構造建築物の構 造性能評価試験法に関寸る研究 委員会報告書, 2002.4

22）藤本盛久：構造用鋼材における転炉材と高炉材，日本建築学会大会学術
講演梗概集 1984 (関東), p.1481·1482,1984.10

23）嶋徹, 中込忠男 : 圧延 $\mathrm{H}$ 形鋼の溶接性を含む機械的性質 電炉材と高 炉材の性能比較, 溶接学会論文集 第 23 巻 第 3 号, p.442•451,2005.8

(2009年 6 月 10 日原稿受理，2009年10月28日採用決定） 